\title{
Evaluation of growth and yield parameters of Sorghum under compartmental bunding in rainfed situation
}

S.A. Biradar, Vivek S. Devarnavadagi, Shivalingappa Hotkar and B. Mallappa

Received : 03.01.2020; Revised : 18.01.2020; Accepted : 03.02.2020

See end of the Paper for authors' affiliation

Correspondence to :

\section{S.A. Biradar}

ICAR-Krishi Vigyan Kendra, Hitnalli Farm, Vijayapur

(Karnataka) India

Email:vivdev2@gmail.com, kvkbijapur@gmail.com
- ABSTRACT : In order to take full advantage of annual precipitation in dry land agriculture, harvesting entire runoff is essential. In a two-year farmer's field demonstration at Vijayapur (Karnataka), moisture conservation practices (compartmental bunding, tied ridgind and conventional method) were evaluated for sorghum grown under rainfed conditions. The results indicated that compartmental bunding conserved 15.5 and 24.07 per cent for 2018-19 and 14.07 and 30.55 per cent for 2019-20 more soil moisture as compared to tied ridging and farmer's practice treatments. Compartmental bunding showed better performance in plant height, grain yield, fodder yield, gross return, net return and B:C ratio over tied ridging and farmer's practice. Compartmental bunding practice also exhibited higher grain yield of sorghum $2740 \mathrm{~kg} \mathrm{ha}^{-1}$ and $2894 \mathrm{~kg} \mathrm{ha}^{-1}$ (for 2018-19 and 2019-20), fodder yield $5621 \mathrm{~kg} \mathrm{ha}^{-1}$ and $5883 \mathrm{~kg} \mathrm{ha}^{-1}$ (for 2018-19 and 2019-20), gross return Rs. 35100 and Rs. 358870 (for 2018-19 and 2019-20), net return Rs. 22700 and Rs. 23580 (for 2018-19 and 2019-20) and B:C ratio 2.79 and 2.87 (for 2018-19 and 2019-20).

- KEY WORDS : Sorghum, Compartmental bunding, Tied ridging, Rainfed situation

-HOW TO CITE THIS PAPER : Biradar, S.A., Devarnavadagi, Vivek S., Hotkar, Shivalingappa and Mallappa, B. (2020). Evaluation of growth and yield parameters of Sorghum under compartmental bunding in rainfed situation. Internat. J. Agric. Engg., 13(1) : 5-9, DOI: 10.15740/HAS/IJAE/ 13.1/5-9. Copyright@2020: Hind Agri-Horticultural Society. 